Letter to the Editor

\title{
Vegetation and climate changes during the late Pliocene and early Pleistocene in SW Turkey - Comment to the published paper by Jiménez-Moreno et al., Quaternary Research, 84 (2015), 448-456
}

\section{Introduction}

There are several Miocene to recent terrestrial and lacustrine basins along the NE-SW-trending Burdur-Fethiye Shear Zone in southwestern Turkey (Elitez and Yaltırak, 2014; Hall et al., 2014; Elitez et al., 2015). The stratigraphic positions of the sequences in these basins are controversial (e.g., Alçiçek, 2015; Elitez et al., 2015). Jiménez-Moreno et al. (2015) interpreted the late Pliocene-early Pleistocene climate based on the vegetation changes at the Ericek and Bıçakçı localities south of the Çameli town. Our observations at these localities (e.g., Elitez et al., 2015) revealed that there are three important geological problems with Jiménez-Moreno et al. (2015): (1) the geographic locations of the samples used in this manuscript are inacurate, (2) the lithologies and the associated thicknesses of the sequences reported in the manuscript are inconsistent, and (3) the positions of the fossils and pollens in an allocthonous stratigraphic succession has no stratigraphic control. The primary aim of this comment is to correctly identify the precise positions of the fossil and pollen data in the stratigraphic sequence rather than an objection to the interpretation of the vegetation and climate data in southwestern Turkey.

\section{Localities, observations and field problems}

\section{Bıçakçı locality}

It is impossible to find the Bıçakçı locality by using the coordinates $\left(37^{\circ} 00^{\prime} 53^{\prime \prime} \mathrm{N}, 29^{\circ} 17^{\prime} 57^{\prime \prime} \mathrm{E}\right)$ given in the manuscript by Jiménez-Moreno et al. (2015). Furthermore, no outcrop photograph exists in the paper. The precise Bıçakçı locality is situated in a valley in the village of Cevizli, $3.2 \mathrm{~km}$ away from Bıçakçı (Fig. 1A; $37^{\circ} 1^{\prime} 27.21^{\prime \prime} \mathrm{N} 29^{\circ} 18^{\prime} 8.20^{\prime \prime} \mathrm{E}$ ). We communicated with Drs. Hüseyin Erten and Nurdan Yavuz at the end of 2015, who have also extensively worked in this area, and obtained field photographs of the outcrops of the Bıçakçı locality. We determined the location used by Jiménez-Moreno et al. (2015) by comparing our detailed field photographs together with two photographs presented in the MSc thesis of Erten (2002; Fig. 1C), one photograph provided to

\footnotetext{
DOIs of original article: http://dx.doi.org/10.1016/j.yqres.2016.03.009, http://dx doi.org/10.1016/j.yqres.2015.09.005.
}

us by Drs. Hüseyin Erten and Nurdan Yavuz. The coordinates of the Bıçakçı locality given by the authors is $\sim 3.3 \mathrm{~km}$ east of the locality on their geological map (Fig. 1B; Jiménez-Moreno et al., 2015, their Fig. 2). Comparison of the lithologic log given by JiménezMoreno et al. (2015) and these photographs, it became obvious that the thickness of the outcrop is $6.3 \mathrm{~m}$ and the lithological characteristics of the sedimentary successions described in this manuscript are entirely different (Fig. 1C, D and E). Jiménez-Moreno et al. (2015) present this outcrop as a 15-m-thick succession. And our detailed study in exactly the same location clearly shows that the thickness of this measurable section is $4.6 \mathrm{~m}$ (Fig. 1C and E). Furthermore, our study shows that the lithologies reported by Jiménez-Moreno et al. (2015) and van den Hoek Ostende et al. (2015a) are largely incorrect (Fig. 1).

\section{Ericek locality}

The coordinates of the Ericek locality provided in the JiménezMoreno et al. (2015) do not indicate the precise location of the sedimentary successions described in the manuscript. Our detailed field studies and mapping clearly document that the location where the stratigraphic section was created by Jiménez-Moreno et al. (2015) and a field photograph of the same location referenced in van den Hoek Ostende et al. (2015b; their Fig. 2) the coordinates of the location is inaccurate (Fig. 1A, B). Both van den Hoek Ostende et al. (2015b; their Fig. 2) and Jiménez-Moreno et al. (2015; their Fig. 4) present the same measured sections, reporting its coordinates as $37^{\circ} 04^{\prime} 12^{\prime \prime} \mathrm{N}, 29^{\circ} 11^{\prime} 55^{\prime \prime} \mathrm{E}$. However, the exact coordinates of this locality is at $37^{\circ} 3^{\prime} 56.89^{\prime \prime} \mathrm{N} 29^{\circ} 11^{\prime} 47.62^{\prime \prime} \mathrm{E}, \sim 502 \mathrm{~m}$ southeast of the location (Fig. 1A) indicated by Jiménez-Moreno et al. (2015). The thickness of this outcrop is reported to be $18 \mathrm{~m}$ by JiménezMoreno et al. (2015; their Fig. 4). This section was previously published as a 13-m-thick succession by van den Hoek Ostende et al. (2015b; their Fig. 2). However, our study in exactly the same location clearly shows that the thickness of this section is $8.8 \mathrm{~m}$. Furthermore, our study shows that the lithologies reported by Jiménez-Moreno et al. (2015) and van den Hoek Ostende et al. (2015b) are also incorrect (Fig. 2A-D). Although the time interval indicated by these fossils (Rhagapodemus, Orientalomys, Mimomys occitanus) are between 3.6 and $3.8 \mathrm{Ma}$ at the Ericek locality (van den Hoek Ostende et al., 2015b; their Fig. 8), these authors suggest 


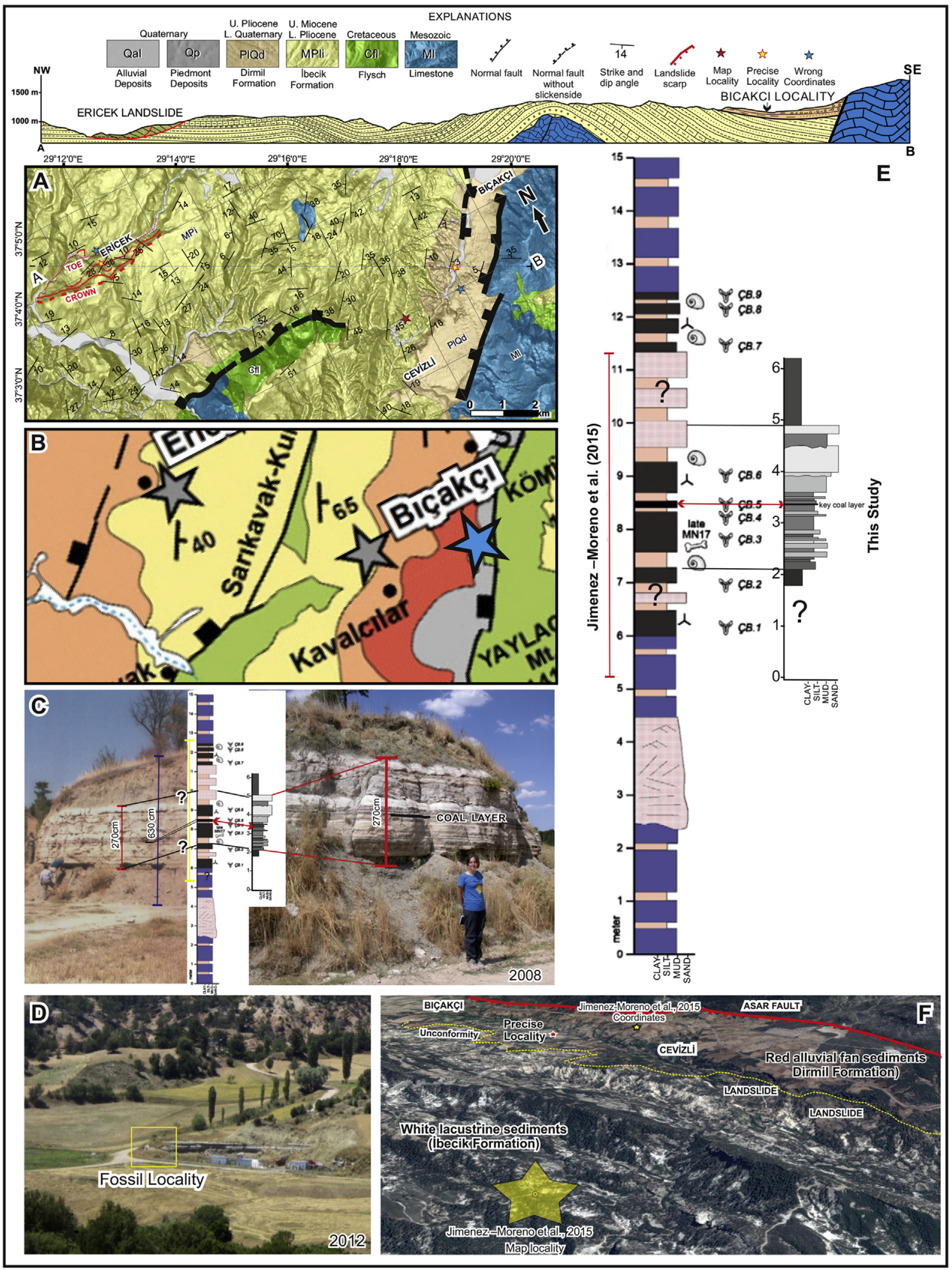

Figure 1. A. The geological map and A-B cross-section of the study area. B. Ericek and Bıçakç localities on the geological map of Jiménez-Moreno et al. (2015). Blue star shows the Bıçakçı locality coordinates suggested by Jiménez-Moreno et al. (2015). C. The photographs and measured sections of Cevizli (Bıçakçı) locality. Left from Erten (2002) and right from our archives. D. Photograph of the Cevizli (Bıçakçı) locality from our archives. E. Correlation between measured sections of Jiménez-Moreno et al. (2015) and this study. F. 3D view of the Bıçakçı-Cevizli area and localities. Small yellow star indicate the coordinates of the Bıçakçı locality and big yellow star indicates the Bıçakçı locality on the geological map in Jiménez-Moreno et al., 2015. Red star show the precise locality. 

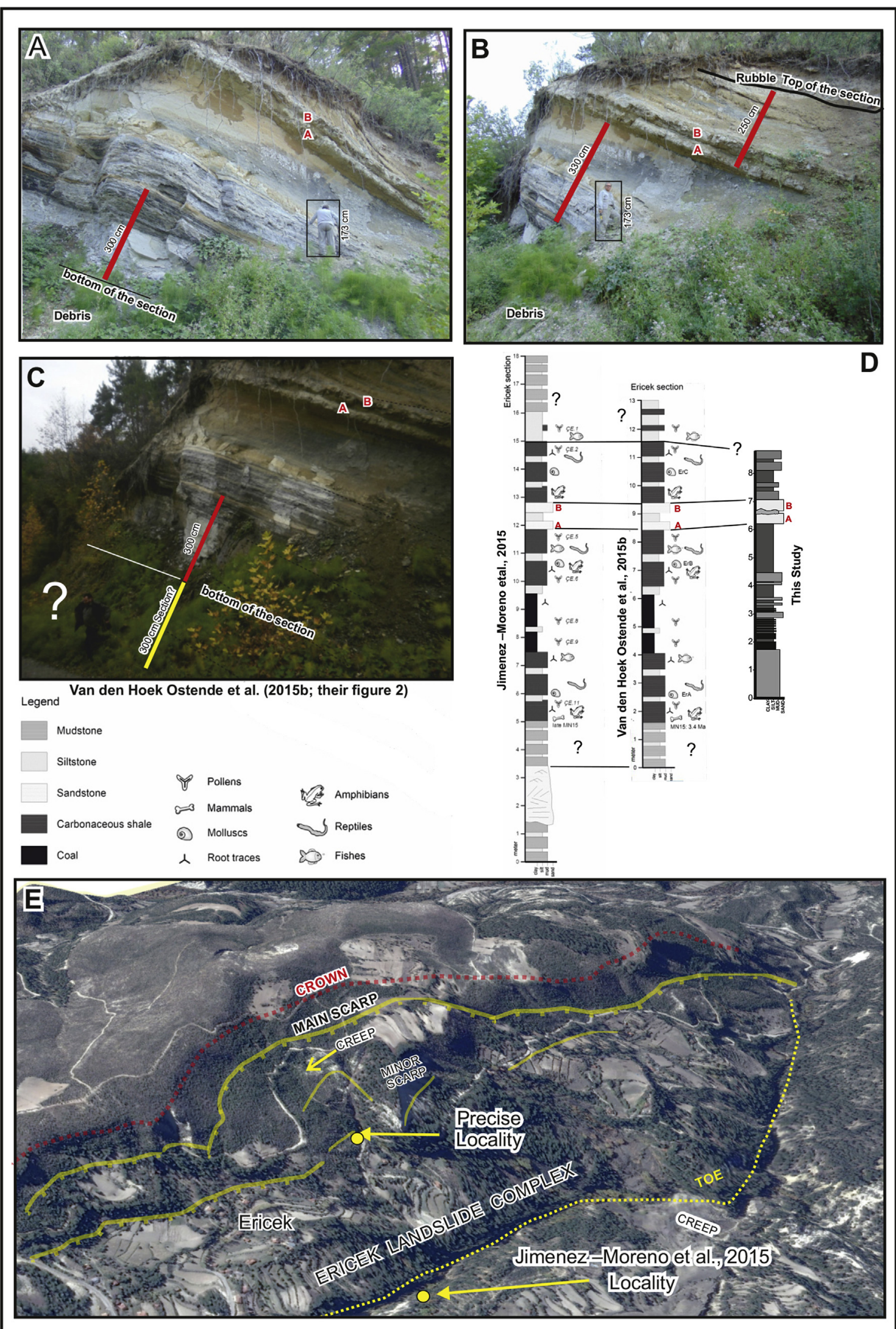

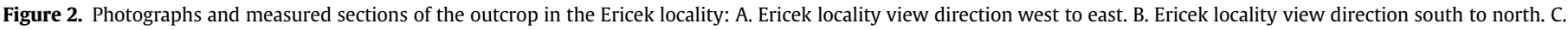

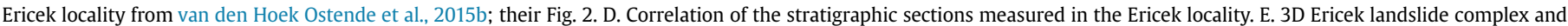
localities suggested by Jiménez-Moreno et al. (2015) and this study. 
a 3.4 Ma age as a best estimate (van den Hoek Ostende, personal communication, 2015a, b). The locality studied by JiménezMoreno et al. (2015) is situated in front of a minor scarp of a landslide (Fig. 2E). This outcrop is a block that dragged both horizontally and vertically for $200-300 \mathrm{~m}$ and tilted (Fig. 2E). The $38^{\circ}$ dip to the east indicative of rotational slides tilted to the landslide scarp (Fig. 1A and 2E).

\section{Regional stratigraphy and fossil ages}

\section{Problems in the stratigraphic sequences}

Jiménez-Moreno et al. (2015) use the stratigraphy published in M.C. Alçiçek's PhD thesis (i.e., Alçiçek, 2001), and the measured sections in this thesis are shown by the authors as proof of this stratigraphy. We examined all measured sections individually and realized that the coordinates of the sections contradict with the localities in the geological map and most of the localities are not topographically and geologically suitable for the construction of measured stratigraphic sections (e.g., Fig. 1A, E, F and detailed section localities: https://www.researchgate.net/publication/ 296327942) However, all subsequent papers use this stratigraphy (e.g., Alçiçek et al., 2004, 2005, 2006; van den Hoek Ostende et al., 2015a, b; Jiménez-Moreno et al., 2015), which shows numerous inconsistencies, thus confusing the reader. Although they suggested that this sequence is a part of Degne Member (Late Pliocene-Early Pleistocene), the coordinates of this locality are placed into the Derindere Member. On the west portion of the map area the stratigraphy from the older to younger is the Derindere, Kumafşarı, Değne members (Jiménez-Moreno et al., 2015; their Fig. 2). However, on the east portion of the map area, the stratigraphy is chronologically reversed and is shown as Değne, Kumafşarı, Derindere members (Jiménez-Moreno et al., 2015; their Fig. 2). This situation can only be encountered when there a recumbent synclinal folding developed. Our geological cross-sections and mapping show that there is no such structure in this area (Fig. 1A). Therefore, the only alternative is that the sequences in the region between Bıçakçı and Suçatı villages were mapped incorrectly by Jiménez-Moreno et al. (2015; their Fig. 2). One inevitably asks the question as to which one is correct? The Bıçakçı locality is given an age range between 2.6 and 1.8 Ma by Alçiçek et al. (2004, $2005,2006)$. However, the same location is given a different age of 2.25 and 2.1 Ma by Jiménez-Moreno et al. (2015). So, why is the Derindere Member the oldest unit as indicated by Alçiçek et al. (2004, 2005, 2006)? Within this framework, the time, environment and climate relationships attributed to this stratigraphy becomes questionable. Furthermore, our field observations and mapping clearly show that the Ericek and the Bıçakçı localities occur in two different formations, exhibiting an unconformable relationship with a 1.2 Ma hiatus (Fig. 1A).

When and how was the Miocene-Pliocene sequence eroded and where did it deposited?

The suggested age for the top of the sequence Jiménez-Moreno et al. (2015) is $2.2 \mathrm{Ma}$. If the sequence was continuous, the end of the lacustrine-river environment would correspond with the beginning of the alluvial fan environment. Thus, the middle Miocene-Pliocene unit would begin eroding at $\sim 2.2 \mathrm{Ma}$ ago. Today there is a semi-formed drainage that causes the erosion of this sequence. The recent Dalaman River Basin is a big part of the Miocene-Pliocene basin. Data published by the General Directorate of Renewable Energy (Elektrik İşleri Etüt İdaresi Genel Müdürlügüu, EIE, 2005) show that $\sim 205 \times 10^{-6} \mathrm{~km}^{3}$ sediment was accumulated at the Suçatı sediment trap in the upper Dalaman Basin between 1969 and 2005. Our calculations based on the stratigraphic position of the Miocene sediments, suggest that the volume of the sediments eroded is $\sim 772 \mathrm{~km}^{3}$. In order to obtain the recent topography, a minimum time of $3.76 \mathrm{Ma}$ is required. The amount of the eroded sediment shows that $1-\mathrm{km}$-thick sediment should be accumulated on a $27 \times 27 \mathrm{~km}$ area during $2 \mathrm{Ma}$ as from the beginning of the Dalaman River. The Dalaman plain is $110 \mathrm{~km}^{2}$. In this case, the sediment thickness must be more than $6 \mathrm{~km}$ and the age must be $2 \mathrm{Ma}$. Ocakoğlu (2012) suggests that a Quaternary delta does not exist in on the continental shelf. According to Hall et al. (2009, 2014), some amount of $~ 500$-m-thick (200-800 m) sequence accumulated above the M-reflector during $5 \mathrm{Ma}$ and located in front of the Dalaman River towards the Rhodes Basin was transported from the eroded basin.

\section{Conclusion}

There are several stratigraphic and lithological problems with Jiménez-Moreno et al. (2015). As the nature of the scientific discussion, the stratigraphic construct suggested in this publication should be reviewed by the help of this comment.

\section{References}

Alçiçek, M.C., 2001. Sedimentological Investigation of Çameli Basin (Late MioceneLate Pliocene). unpublished PhD Thesis. SW Anatolia Ankara University, p. 110 Alçiçek, M.C., 2015. Comment on "The Fethiye-Burdur Fault Zone: a component of upper plate extension of the subduction transform edge propagator fault linking Hellenic and Cyprus Arcs, Eastern Mediterranean. Tectonophysics 635 80-99" by J. Hall, A.E. Aksu, İ. Elitez, C. Yaltırak, G. Çiftçi. Tectonophysics 128 $1-4$ (in this volume).

Alçiçek, M.C., Kazancı, N., Özkul, M., 2005. Multiple rifting pulses and sedimentation in the Çameli Basin, southwestern Anatolia. Sedimentary Geology 173 409-431.

Alçiçek, M.C., Kazancı, N., Özkul, M., Sen, S., 2004. Sedimentary fill and geological evolution of the Çameli (Denizli) Neogene Basin. Bulletin of the Mineral Research and Exploration 128, 99-123.

Alçiçek, M.C., Ten Veen, J.H., Özkul, M., 2006. Neotectonic development of the Cameli Basin, southwestern Anatolia, Turkey. In: Robertson, A.H.F., Mountrakis, D. (Eds.), Tectonic Development of the Eastern Mediterranean Region, 260 Geological Society of London, Special Publication, pp. 591-611.

EIE, 2005. Suspended Sediment Data for Surface Waters in Turkey, p. 451.

Elitez, İ., Yaltırak, C., 2014. Miocene-Quaternary Geodynamics of Çameli Basin, Burdur-Fethiye Shear Zone (SW Turkey). Geological Bulletin of Turkey 57 (3) 41-67.

Elitez, I., Yaltırak, C., Hall, J., Aksu, A.E., Çifçi, G., 2015. Reply to the comment by M.C. Alçiçek on "The Fethiye-Burdur Fault Zone: a component of upper plate extension of the subduction transform edge propagator fault linking Hellenic and Cyprus Arcs, Eastern Mediterranean". Tectonophysics 635, 80-99. http:// dx.doi.org/10.1016/j.tecto.2015.04.0. Tectonophysics.

Erten, H., 2002. Stratigraphy and Micromammal Investigation of the AcıpayamCameli Area, unpublished Ms Thesis. Pamukkale University, p. 66.

Hall, J., Aksu, A.E., Elitez, I., Yaltırak, C., Çifçi, G., 2014. The Fethiye-Burdur Fault Zone: a component of upper plate extension of the subduction transform edge propagator fault linking Hellenic and Cyprus Arcs. Eastern Mediterranean Tectonophysics 635, 80-99.

Hall, J., Aksu, A.E., Yaltırak, C., Winsdor, J., 2009. Structural architecture of the Rhodes Basin: a deep depocentre that evolved since the Pliocene at the junction of Hellenic and Cyprus Arcs, eastern Mediterranean. Marine Geology 258 (1-4), $1-23$.

Jiménez-Moreno, G., Alçiçek, H., Alçiçek, C., van den Hoek Ostende, L. Wesselingh, F.P., 2015. Vegetation and climate changes during the late Pliocene and early Pleistocene in SW Anatolia. Quaternary Research 84 (3), 448-456.

Ocakoğlu, N., 2012. Investigation of Fethiye-Marmaris Bay (SW Anatolia): seismic and morphologic evidences from the missing link between the Pliny Trench and the Fethiye-Burdur Fault Zone. Geo-Marine Letters 32 (1), 17-28.

van den Hoek Ostende, L.W., Diepenveen, F., Tesakov, A., Saraç, G., Mayhew, D. Alçiçek, M.C., 2015a. On the brink: micromammals from the latest Villanyian from Bıçakçı (Anatolia). Geological Journal 50, 230-245.

van den Hoek Ostende, L.W., van Bennekom, L., Alçiçek, M.C., Murray, A.M., Gardner, J.D., Wesselingh, F.P., Alçiçek, H., Tesakov, A.S., 2015b. Ericek, a new 
Pliocene vertebrate locality from the Çameli Basin (southwestern Anatolia, Turkey). Palaeobiodiversity and Palaeoenvironments 95, 305-320.

İem Elitez*, Cenk Yaltırak, Murat Sahin İstanbul Technical University, Faculty of Mines, Department of Geological Engineering, Maslak, Istanbul, Turkey
* Corresponding author. E-mail address: elitezi@itu.edu.tr (İ. Elitez).

16 February 2016 